\title{
Association between polymorphisms of TAS2R16 and susceptibility to colorectal cancer
}

\author{
Jonathan Barontini ${ }^{1}$, Marco Antinucci ${ }^{1}$, Sergio Tofanelli ${ }^{1}$, Maurizio Cammalleri ${ }^{1}$, Massimo Dal Monte ${ }^{1}$, \\ Federica Gemignani ${ }^{1}$, Pavel Vodicka ${ }^{2,3,4}$, Roberto Marangoni ${ }^{1}$, Ludmila Vodickova ${ }^{2,3,4}$, Juozas Kupcinskas ${ }^{5}$, \\ Veronika Vymetalkova ${ }^{2,3}$, Asta Forsti ${ }^{6}$, Federico Canzian ${ }^{7}$, Angelika Stein ${ }^{7}$, Victor Moreno ${ }^{8}$, Nicola Mastrodonato ${ }^{9}$, \\ Francesca Tavano ${ }^{9}$, Anna Panza ${ }^{9}$, Roberto Barale ${ }^{1}$, Stefano Landi ${ }^{*}$ and Daniele Campa ${ }^{1}$
}

\begin{abstract}
Background: Genetics plays an important role in the susceptibility to sporadic colorectal cancer (CRC). In the last 10 years genome-wide association studies (GWAS) have identified over 40 independent low penetrance polymorphic variants. However, these loci only explain around $1-4 \%$ of CRC heritability, highlighting the dire need of identifying novel risk loci. In this study, we focused our attention on the genetic variability of the TAS2R16 gene, encoding for one of the bitter taste receptors that selectively binds to salicin, a natural antipyretic that resembles aspirin. Given the importance of inflammation in CRC, we tested whether polymorphic variants in this gene could affect the risk of developing this neoplasia hypothesizing a role of TAS2R16 in modulating chronic inflammation within the gut.

Methods: We performed an association study using 6 tagging SNPs, (rs860170, rs978739, rs1357949, rs1525489, rs6466849, rs10268496) that cover all TAS2R16 genetic variability. The study was carried out on 1902 CRC cases and 1532 control individuals from four European countries.

Results: We did not find any statistically significant association between risk of developing CRC and selected SNPs. However, after stratification by histology (colon vs. rectum) we found that rs1525489 was associated with increased risk of rectal cancer with a $\left(P_{\text {trend }}\right.$ of $\left.=0.0071\right)$.
\end{abstract}

Conclusions: Our data suggest that polymorphisms within TAS2R16 gene do not have a strong influence on colon cancer susceptibility, but a possible role in rectal cancer should be further evaluated in larger cohorts.

Keywords: Taste receptors, TAS2R16, Polymorphisms, Colon cancer, Rectal cancer, Colorectal cancer, Cancer risk, Genetic association study

\section{Background}

Colorectal cancer (CRC) is the third most commonly diagnosed cancer worldwide [1]. Several environmental/life style risk factors have been identified for CRC, such as obesity, sedentary behavior, high red meat consumption, high intake of hyper caloric foods, diets rich in fat and poor in fiber, tobacco smoking, alcohol consumption and diabetes [2]. In addition gut inflammation, due to chronic conditions such as ulcerative colitis and Crohn's disease, is an established risk factor [2]. Also genetics is hypothesized to

\footnotetext{
* Correspondence: stefano.landi@unipi.it

'Department of Biology, University of Pisa, Via Derna 1, 56100 Pisa, Italy Full list of author information is available at the end of the article
}

play an important role for the sporadic form. In the last 10 years genome-wide association studies (GWAS) have identified over 40 independent low penetrance polymorphic variants [3]. Besides GWAS, an overwhelming number of hypothesis-driven studies carried out on specific candidate genes highlighted variants belonging to multiple pathways to be connected to CRC risk. The majority of the studies focused on SNPs within DNA repair genes [4], xenobiotic metabolism and transport genes [5-14], inflammatory response genes [15-17], hormone metabolisms [18, 19] and more recently miRNAs $[20,21]$. Our group and others have also analyzed the possible involvement of taste receptor genes in CRC risk [22-24]. In the human genome, there 
are 25 functional genes and 11 pseudogenes belonging to the TAS2Rs gene family. It has already been ascertained that polymorphic variants in these genes are responsible for the variability observed in several human phenotypes and life habits such as alcohol consumption [25, 26], and nicotine dependence [27]. However, taste receptors seem to have also less obvious functions. In fact taste receptors certainly do not only have a role in taste perception, as documented by their ectopic expression in a variety of extra-oral tissues including gut [28-31]. In this study we focused our attention on the genetic variability of the TAS2R16 gene whose encoded receptor selectively binds to salicin [32], a natural anti-inflammatory and analgesic agent extracted from willow bark and resembling aspirin [33]. Given the similarities between salicin and aspirin it is reasonable to postulate that variants within the TAS2R16 gene could affect the receptor activity following its binding with ligands such as salicin or aspirin. In particular, aspirin intake is an established factor reducing the risk to develop CRC. In fact, there are evidences from case-control and cohort studies indicating benefit from long term use of aspirin at low dose in colorectal cancer chemoprevention [34]. This effect could be elicited through an anti-inflammatory activity or to the binding to specific receptors in the gut. Furthermore, there are indications that regular use of aspirin is associated with improved survival for patients with colorectal cancer [35]. The hypothesis is corroborated by a previous study (Campbell and colleagues) conducted on two different African populations, describing that the polymorphic variant rs846664 within TAS2R16 confers different sensitivities to salicin [36]. Unfortunately, this finding could not be replicated among Caucasians since this SNP is monomorphic in this population. However, according to this base of knowledge, it could be hypothesized that TAS2R16 could modulate chronic inflammation in the gut. Alternatively, the receptor, upon binding with its natural ligands, could affect the individual risk of cancer with mechanisms similar to those observed following a long term aspirin intake. Thus, in the present work we tested whether polymorphic variants within TAS2R16 could affect the risk of developing CRC. The study was carried out in a large cohort of European individuals.

\section{Methods}

\section{Study population}

A total of 2252 CRC case subjects and 1630 controls were collected in four European countries (Czech Republic, Italy, Lithuania and Spain). CRC patients had histological verification of colorectal adenocarcinoma. Controls were collected in the same hospitals and in the same time frame as the cases among hospitalized individuals without neoplastic diseases. A more detailed description of the sampling and collection methods has been provided elsewhere [9, 37-39]. For the cases we collected information about gender, age at diagnosis, tumor localization (colon or rectum), while for the controls we have information on gender and age at sampling.

\section{SNPs selection}

We used tagging SNPs to cover all the common genetic variability of TAS2R16. We selected the gene region and added $4 \mathrm{k}$ base pairs on the 5 prime and 3 prime directions. According to HapMap 3 database, within the selected region there are 24 known common SNPs with a MAF $>0.05$ among Caucasians. Using the software Haploview [40] we selected six tagging SNPs by setting the LD threshold at $r^{2} \geq 0.8$. The final selection of the SNPs resulted in rs860170, rs978739, rs1357949, rs1525489, rs6466849, and rs10268496 covering $87 \%$ of the common genetic variability.

\section{Sample preparation and genotyping}

DNA was extracted from whole blood. Samples were kept frozen until used. Genotyping was performed on 384 well plates using the KASP (LGC, Teddington, UK) and TaqMan (Thermo Fisher, Waltham, MA USA) genotyping chemistry. In each plate there was DNA from cases and controls in order to avoid bias due to genotyping. We included a mean of 15 duplicated samples for plate to be used as quality controls. After the PCR the plates were "read" via the spectrophotometer Fluostar Omega $(\Omega) \quad\left(\right.$ BMG.LABTECH $\left.^{\circ}\right)$ and genotyping calls were done using the KlusterCaller software (LGC Group Teddington, UK).

\section{Statistical analysis}

The observed genotype frequencies of all SNPs were tested for deviation from Hardy-Weinberg equilibrium (HWE) in controls. The association between the genotypes of all polymorphisms and CRC risk was estimated using an unconditional logistic regression computing odds ratios (OR), 95\% confidence intervals (95\% CIs) and $P$ values. The common allele among the controls was assigned as the reference category and the co-dominant inheritance model was assessed. All analyses were adjusted for age (at diagnosis for cases and at sampling for controls), gender and country origin. We also performed stratified analyses for country of origin and tumor site. The significance level in each test was adjusted according to the Bonferroni's correction, namely adjusted $P=\alpha /$ number of individual tests $(0.05 / 6=0.008)$.

\section{Bioinformatic tools}

We carried out bioinformatic analyses to assess the possible functional effect of the studied polymorphisms, for example to detect if the nucleotide sequences of the polymorphisms are targets of transcription factors or if they are situated in DNase sensitivity region. Specifically 
we have used RegulomeDB V1.1 [41] and Haploreg V4.1 [42]; to test whether the polymorphisms could have a known regulatory impact. Additionally, we used the data available in the GTEx project V6 to identify expression of quantitative trait loci (eQTLs) [43].

\section{Results}

\section{Data filtering and quality control}

We examined 6 SNPs belonging to the TAS2R16 gene to assess their possible role in the risk of developing CRC. We have genotyped up to 3882 individuals (2252 CRC cases and 1630 controls) enrolled in the Czech Republic, Lithuania, Italy and Spain. The distributions of the genotype frequencies for all the variants included in the study were in accordance with HWE. Four hundred forty-eight (448) subjects (346 CRC cases 102 controls) for which we did not have covariates data or that did not pass quality control (call rate $<75 \%$ ) were removed from subsequent analyses, leaving a total of 3434 subjects (1902 CRC cases and 1532 controls) for statistical analysis. All the relevant characteristics of the population used in the analyses are shown in Table 1. The average SNP call rate was $96.24 \%$ with a minimum of $98.16 \%$ (rs1525489) and a maximum of $99.66 \%$ ( $r s 10268496)$. The analysis of the samples duplicated for quality control showed a concordance greater than $99 \%$. All the frequencies, call rate and HWE values of each polymorphism are reported in Additional file 1: Table S1.

\section{Effect of SNPs on colorectal cancer risk}

Overall, we did not observe any statistically significant association between selected SNPs and risk of CRC. The polymorphism with the lowest $p$-value was rs1525489 showing a p-trend of $P=0.084$. Following the stratification by tumor site (colon / rectum) we found that rs1525489 showed a marginal/borderline significance with increased risk of rectal cancer at nominal level of $\left(\mathrm{P}_{\text {trend }}=0.0071\right)$, while the associations between the SNPs and colon cancer were similar to those considering the two strata together (Table 2). However, performing a casecase analysis (colon vs. rectum) we did not observe any heterogeneity. When stratifying for country of origin we obtained one marginally significant value. In the Lithuanian case control study subjects the minor (C) allele of rs1525489 was associated with an increased risk of developing CRC with a nominal $P_{\text {trend }}=0.047$. We observed the same trend also in the Spanish sub-population $(P=0.051)$. The stratified analyses are reported in Additional file 2: Table S2, Additional file 3: Table S3, Additional file 4: Table S4, and Additional file 5: Table S5.

\section{Bioinformatic analysis}

We used three bioinformatic tools to identify possible functional properties of rs1525489, the SNP showing the best results from a statistical point of view. RegulomeDB showed a score of six (which means minimal binding evidence). Using HaploReg we did not observe any potentially relevant data. GTEx database did not show any statistically significant eQTLs between the SNP and nearby genes in any of the tissues present in the database.

\section{Discussion}

To further expand our knowledge on CRC genetic susceptibility we investigated whether polymorphic variants within TAS2R16 could have a role in the etiology of the disease. Our hypothesis finds its rationale on several epidemiologic evidences that polymorphic variants within taste receptor genes could be associated with risk of cancer development. For instance TAS2R38 SNPs were found to be associated with risk of developing CRC in two different populations of Caucasian origin [23], while SNPs within TAS2R38 and TAS1Rs were associated with increased risk of gastric cancer [44, 45]. In this study we examined the genetic variability of TAS2R16 gene because the receptor binds different compounds including salicin, a natural anti-inflammatory substance which is very similar to aspirin [32, 33]. One of the strongest risk factors for CRC is represented by chronic inflammation especially arisen from diseases that trigger a continuous inflammatory responses such as ulcerative colitis and Crohn's disease [2]. Aspirin treatment reduces the risk of CRC [2] and therefore genetic variants that modulate the efficiency or the expression of the receptor may play a role in CRC development. Since polymorphisms in taste genes are generally functional as reflected in their effect in a multitude of phenotypes, it is reasonable to hypothesize a possible link between TAS2R16 allelic

Table 1 Population in study

\begin{tabular}{|c|c|c|c|c|c|c|c|c|}
\hline \multirow{2}{*}{$\begin{array}{l}\text { Country of } \\
\text { origin }\end{array}$} & \multicolumn{4}{|c|}{ Colorectal Cancer Cases } & \multicolumn{4}{|c|}{ Controls } \\
\hline & Males & Females & Total & Mean Age & Males & Females & Total & Mean Age \\
\hline Czech Republic & 588 & 400 & 988 & 61.92 & 393 & 296 & 689 & 54.87 \\
\hline Lithuania & 102 & 76 & 178 & 67.04 & 91 & 92 & 183 & 57.29 \\
\hline Italy & 179 & 142 & 321 & 65.97 & 252 & 94 & 346 & 51.94 \\
\hline Spain & 248 & 167 & 415 & 66.35 & 166 & 148 & 314 & 65.34 \\
\hline Total & 1117 & 785 & 1902 & 64.09 & 902 & 630 & 1532 & 56.69 \\
\hline
\end{tabular}


Table 2 Association between colorectal cancer risk and SNPs in the TAS2R16 region stratified by histology

\begin{tabular}{|c|c|c|c|c|c|c|c|c|c|c|c|c|c|c|}
\hline \multirow[t]{2}{*}{ SNP } & \multirow{2}{*}{$\begin{array}{l}\text { Alleles } \\
\text { (Major/ } \\
\text { minor) }\end{array}$} & \multirow{2}{*}{ Site } & \multicolumn{3}{|c|}{ Case/Control $^{a}$} & \multirow{2}{*}{$\begin{array}{l}\text { MM vs } \\
M^{b}\end{array}$} & \multirow{2}{*}{$\begin{array}{l}P \\
\text { value }\end{array}$} & \multirow{2}{*}{$\begin{array}{l}\text { MM vs } \\
\mathrm{mm}^{\mathrm{b}}\end{array}$} & \multirow{2}{*}{$\begin{array}{l}P \\
\text { value }\end{array}$} & \multirow{2}{*}{$\begin{array}{l}\text { MM vs Mm } \\
+m^{b}\end{array}$} & \multirow{2}{*}{$\begin{array}{l}P \\
\text { value }\end{array}$} & \multirow{2}{*}{$\begin{array}{l}\mathrm{MM}+\mathrm{Mm} \\
\text { vs mm }\end{array}$} & \multirow{2}{*}{$\begin{array}{l}P \\
\text { value }\end{array}$} & \multirow{2}{*}{$\begin{array}{l}\mathrm{P} \\
\text { trend }\end{array}$} \\
\hline & & & $\overline{\mathrm{MM}}$ & $\mathrm{Mm}$ & $\mathrm{mm}$ & & & & & & & & & \\
\hline \multirow[t]{3}{*}{ rs860170 } & \multirow[t]{3}{*}{$A / G$} & All & $785 / 653$ & $\begin{array}{l}846 / \\
681\end{array}$ & $\begin{array}{l}245 / \\
184\end{array}$ & $\begin{array}{l}1.04(0.9- \\
1.22)\end{array}$ & 0.57 & $\begin{array}{l}1.05(0.83- \\
1.32)\end{array}$ & 0.69 & $\begin{array}{l}1.05(0.9- \\
1.21)\end{array}$ & 0.55 & $\begin{array}{l}1.03(0.83- \\
1.27)\end{array}$ & 0.82 & 0.37 \\
\hline & & Colon & $447 / 653$ & $\begin{array}{l}487 / \\
681\end{array}$ & $\begin{array}{l}141 / \\
184\end{array}$ & $\begin{array}{l}1.03(0.87- \\
1.23)\end{array}$ & 0.73 & $\begin{array}{l}1.07(0.82- \\
1.4)\end{array}$ & 0.52 & $\begin{array}{l}1.04(0.88- \\
1.23)\end{array}$ & 0.64 & $\begin{array}{l}1.06(0.82- \\
1.35)\end{array}$ & 0.67 & 0.37 \\
\hline & & Rectum & $231 / 653$ & $\begin{array}{l}256 / \\
681\end{array}$ & $\begin{array}{l}68 / \\
184\end{array}$ & $\begin{array}{l}1.06(0.85- \\
1.32)\end{array}$ & 0.61 & $\begin{array}{l}1.02(0.74- \\
1.43)\end{array}$ & 0.89 & $\begin{array}{l}1.05(0.85- \\
1.29)\end{array}$ & 0.64 & $\begin{array}{l}0.99(0.73- \\
1.36)\end{array}$ & 0.97 & 0.65 \\
\hline \multirow[t]{3}{*}{ rs978739 } & \multirow[t]{3}{*}{$A / G$} & All & $830 / 693$ & $\begin{array}{l}777 / \\
678\end{array}$ & $\begin{array}{l}182 / \\
156\end{array}$ & $\begin{array}{l}0.97(0.83- \\
1.13)\end{array}$ & 0.67 & $\begin{array}{l}0.98(0.77- \\
1.26)\end{array}$ & 0.89 & $\begin{array}{l}0.97(0.84- \\
1.12)\end{array}$ & 0.68 & $1(0.79-1.27)$ & 0.99 & 0.65 \\
\hline & & Colon & $487 / 693$ & $\begin{array}{l}422 / \\
678\end{array}$ & $\begin{array}{l}97 / \\
156\end{array}$ & $\begin{array}{l}0.9(0.75- \\
1.07)\end{array}$ & 0.22 & $\begin{array}{l}0.88(0.65- \\
1.17)\end{array}$ & 0.37 & $\begin{array}{l}0.89(0.75- \\
1.05)\end{array}$ & 0.18 & $\begin{array}{l}0.92(0.7- \\
1.22)\end{array}$ & 0.58 & 0.18 \\
\hline & & Rectum & $240 / 693$ & $\begin{array}{l}222 / \\
678\end{array}$ & $\begin{array}{l}71 / \\
156\end{array}$ & $\begin{array}{l}0.97(0.78- \\
1.22)\end{array}$ & 0.82 & $\begin{array}{l}1.36(0.97- \\
1.9)\end{array}$ & 0.08 & $\begin{array}{l}1.04(0.85- \\
1.29)\end{array}$ & 0.68 & $1.37(1-1.89)$ & 0.05 & 0.30 \\
\hline \multirow[t]{3}{*}{ rs1357949 } & \multirow[t]{3}{*}{$\mathrm{T} / \mathrm{C}$} & All & $927 / 719$ & $\begin{array}{l}761 / \\
659\end{array}$ & $\begin{array}{l}180 / \\
145\end{array}$ & $\begin{array}{l}0.91(0.78- \\
1.05)\end{array}$ & 0.20 & $\begin{array}{l}0.95(0.74- \\
1.23)\end{array}$ & 0.71 & $\begin{array}{l}0.91(0.79- \\
1.06)\end{array}$ & 0.22 & $1(0.78-1.27)$ & 0.99 & 0.31 \\
\hline & & Colon & $512 / 719$ & $\begin{array}{l}443 / \\
659\end{array}$ & $\begin{array}{l}110 / \\
145\end{array}$ & $\begin{array}{l}0.97(0.81- \\
1.15)\end{array}$ & 0.72 & $\begin{array}{l}1.09(0.82- \\
1.46)\end{array}$ & 0.54 & $\begin{array}{l}0.99(0.84- \\
1.17)\end{array}$ & 0.92 & $\begin{array}{l}1.11(0.84- \\
1.46)\end{array}$ & 0.46 & 0.98 \\
\hline & & Rectum & 292/719 & $\begin{array}{l}211 / \\
659\end{array}$ & $\begin{array}{l}50 / \\
145\end{array}$ & $\begin{array}{l}0.78(0.63- \\
0.97)\end{array}$ & 0.03 & $\begin{array}{l}0.82(0.57- \\
1.19)\end{array}$ & 0.30 & $\begin{array}{l}0.79(0.64- \\
0.97)\end{array}$ & 0.02 & $\begin{array}{l}0.92(0.65- \\
1.32)\end{array}$ & 0.66 & 0.06 \\
\hline \multirow[t]{3}{*}{ rs1525489 } & \multirow[t]{3}{*}{$\mathrm{T} / \mathrm{C}$} & All & $\begin{array}{l}1728 / \\
956\end{array}$ & $\begin{array}{l}145 / \\
62\end{array}$ & $1 / 0$ & $\begin{array}{l}1.24(0.88- \\
1.73)\end{array}$ & 0.22 & - & - & $\begin{array}{l}1.22(0.88- \\
1.70)\end{array}$ & 0.23 & - & - & 0.08 \\
\hline & & Colon & 992/956 & $77 / 62$ & 0/0 & $\begin{array}{l}1.22(0.83- \\
1.8)\end{array}$ & 0.30 & - & - & $\begin{array}{l}1.22(0.83- \\
1.8)\end{array}$ & 0.30 & - & - & 0.31 \\
\hline & & Rectum & $505 / 956$ & $53 / 62$ & $1 / 0$ & $\begin{array}{l}1.59(1.03- \\
2.43)\end{array}$ & 0.03 & - & - & $\begin{array}{l}1.62(1.06- \\
2.47)\end{array}$ & 0.03 & - & - & 0.007 \\
\hline \multirow[t]{3}{*}{ rs6466849 } & \multirow[t]{3}{*}{$\mathrm{G} / \mathrm{A}$} & All & $\begin{array}{l}1276 / \\
1024\end{array}$ & $\begin{array}{l}524 / \\
452\end{array}$ & $62 / 52$ & $\begin{array}{l}0.97(0.83- \\
1.14)\end{array}$ & 0.75 & $\begin{array}{l}1.01(0.68- \\
1.51)\end{array}$ & 0.95 & $\begin{array}{l}0.98(0.84- \\
1.14)\end{array}$ & 0.78 & $\begin{array}{l}1.02(0.69- \\
1.51)\end{array}$ & 0.92 & 0.40 \\
\hline & & Colon & $\begin{array}{l}748 / \\
1024\end{array}$ & $\begin{array}{l}284 / \\
452\end{array}$ & $36 / 52$ & $\begin{array}{l}0.88(0.73- \\
1.05)\end{array}$ & 0.16 & $\begin{array}{l}0.97(0.61- \\
1.53)\end{array}$ & 0.88 & $\begin{array}{l}0.88(0.74- \\
1.06)\end{array}$ & 0.18 & $1(0.64-1.58)$ & 0.99 & 0.16 \\
\hline & & Rectum & $\begin{array}{l}376 / \\
1024\end{array}$ & $\begin{array}{l}156 / \\
452\end{array}$ & $22 / 52$ & $1(0.8-1.26)$ & 0.97 & $\begin{array}{l}1.25(0.73- \\
2.15)\end{array}$ & 0.42 & $\begin{array}{l}1.03(0.83- \\
1.28)\end{array}$ & 0.79 & $\begin{array}{l}1.25(0.73- \\
2.13)\end{array}$ & 0.42 & 0.92 \\
\hline \multirow[t]{3}{*}{ rs10268496 } & \multirow[t]{3}{*}{$\mathrm{T} / \mathrm{G}$} & All & $\begin{array}{l}1200 / \\
951\end{array}$ & $\begin{array}{l}596 / \\
510\end{array}$ & $\begin{array}{l}100 / \\
70\end{array}$ & $\begin{array}{l}0.92(0.79- \\
1.07)\end{array}$ & 0.28 & $\begin{array}{l}1.07(0.77- \\
1.49)\end{array}$ & 0.70 & $\begin{array}{l}0.94(0.81- \\
1.08)\end{array}$ & 0.38 & $\begin{array}{l}1.1(0.79- \\
1.53)\end{array}$ & 0.57 & 0.81 \\
\hline & & Colon & $678 / 951$ & $\begin{array}{l}342 / \\
510\end{array}$ & $62 / 70$ & $\begin{array}{l}0.94(0.79- \\
1.12)\end{array}$ & 0.49 & $\begin{array}{l}1.18(0.81- \\
1.71)\end{array}$ & 0.39 & $\begin{array}{l}0.97(0.82- \\
1.15)\end{array}$ & 0.72 & $\begin{array}{l}1.2(0.83- \\
1.74)\end{array}$ & 0.33 & 0.79 \\
\hline & & Rectum & $364 / 951$ & $\begin{array}{l}175 / \\
510\end{array}$ & $25 / 70$ & $\begin{array}{l}0.88(0.7- \\
1.09)\end{array}$ & 0.24 & $\begin{array}{l}0.86(0.53- \\
1.41)\end{array}$ & 0.55 & $\begin{array}{l}0.87(0.71- \\
1.08)\end{array}$ & 0.21 & $\begin{array}{l}0.9(0.55- \\
1.46)\end{array}$ & 0.67 & 0.37 \\
\hline
\end{tabular}

${ }^{a}$ Numbers may not add up 100\% to genotyping failure, covariate missing values or DNA depletion

${ }^{\mathrm{b}} \mathrm{MM}$ vs $\mathrm{Mm}=$ Common homozygous carriers vs heterozygous; $\mathrm{MM}$ vs $\mathrm{mm}=$ Common homozygous vs rare homozygous; $\mathrm{MM}$ vs $\mathrm{Mm}+\mathrm{mm}=$ Common homozygous vs heterozygous + rare homozygous (Dominant Model); $\mathrm{MM}+\mathrm{Mm}$ vs $\mathrm{mm}=$ Common homozygous + heterozygous vs rare homozygous. Odds Ratio (95\% confidence interval).All analysis are adjusted for age, gender and country of origin

variants and CRC risk. To perform our analysis 6 SNPs tagging the common variants present in the region of the gene under examination were chosen. The selection was mainly based on linkage disequilibrium scores between all the variants of the region. Our results seem to suggest no association between the selected polymorphism and risk of developing CRC. The signal closest to the significance threshold of $P<0.05$ was observed for rs1525489. For this SNP stratifying the analysis for country of origin we found in the Lithuanian and in the Spanish sub-populations a tendency for individuals with at least $1 \mathrm{C}$ allele of the rs1525489 polymorphism to have and increased risk of developing CRC (P 0.047 and $P=0.051$, respectively). However, these associations were not statistically significant following Bonferroni's correction. A possible explanation for this association is that this SNP interact with a lifestyle factor or a dietary habit a factor that we do not account for in the analysis. However, this difference maybe just due to statistical fluctuations. Schembre and colleagues have performed a study investigating two TAS2R16 polymorphic variants (rs846672 and rs846664) in relation to the risk of developing colorectal adenoma [24]. Even though the study is rather small (914 cases of three different ethnic groups) 
their results are concordant with ours, suggesting an overall no effect of the two variants in the disease. The rs846664 SNP is monomorphic in Caucasian and therefore was not typed in our study while rs 846672 is in complete LD with rs860170 that was used in the present study $\left(\mathrm{r}^{2}=1\right.$ in European Hapmap Ceu). When analyzing separately colon and rectum, we observed an association between the minor allele of the rs1525489 and an increased risk of developing specifically rectal cancer. This association was showed to have a marginal/borderline statistically significance also after Bonferroni's correction $(P=0.0071)$. However, this finding must be taken with caution since it is the result of a stratified analysis, on a limited sample size, and it is also difficult to explain from a biological point of view. In fact, the bioinformatics tools did not reveal any possible functional effect for this SNP nor for the variants in LD with it. We acknowledge that the present study has several limitations. We could not collect information on aspirin use and therefore we could not analyze any possible interaction with the SNP analyzed. Moreover, cases and controls are not individually matched for age and gender, however we have adjusted all the analyses for these two variables to minimize their possible effect. We had a power greater than $80 \%$ (considering an alpha of 0.05 / $6=0.008)$ to find an association with an OR of 1.25 or higher for all the SNPs in analysis with the exception of rs1525489 that had a low MAF and for which we had the power to find OR greater than 1.53. An OR of 1.25 is compatible with the ORs found by GWAS in CRC [3]. Using a tagging approach, we have covered most of the common variability of the gene region excluding the possibility of having missed an association with a common but un-typed variant.

\section{Conclusions}

Thus, although we have to be very cautious with the results, our data suggest that polymorphisms of the TAS2R16 gene do not have a strong influence on colon cancer susceptibility, but that the study should be replicated in large cohorts to better evaluate the effect of rs1525489 on the risk of rectal cancer.

\section{Additional files}

Additional file 1: Table S1. Description of data stratified analysis frequencies, call rate and Hardy-Weinberg equilibrium values of each polymorphism. (DOCX $19 \mathrm{~kb}$ )

Additional file 2: Table S2. Description of data Association between colon/rectal cancer risk and SNPs in the TAS2R16 region considering only the Czech Republic. (DOCX $17 \mathrm{~kb}$ )

Additional file 3: Table S3. Description of data Association between colon/rectalcancer risk and SNPs in the TAS2R16 region considering only Lithuania. (DOCX $18 \mathrm{~kb}$ )
Additional file 4: Table S4. Description of data Association between colon/rectalcancer risk and SNPs in the TAS2R16 region considering only Italy. (DOCX $17 \mathrm{~kb})$

Additional file 5: Table S5. Description of data Association between colon/rectal cancer risk and SNPs in the TAS2R16 region considering only Spain. (DOCX 17 kb)

\section{Abbreviations}

Cl: Confidence interval; CRC: Colorectal cancer; eQTL: Expression quantitative trait loci; GWAS: Genome-wide association studies; HWE: Hardy-Weinberg equilibrium; LD: Linkage disequilibrium; MAF: Minor allele frequency; OR: Odds ratio; SNP: Single nucleotide polymorphism

\section{Acknowledgements}

Not applicable.

\section{Funding}

This work was supported by the University of Pisa PRA 2016 Grant. VM was supported by Instituto de Salud Carlos III, co-funded by FEDER funds - a way to build Europe- PI1400616 and Catalan Government DURSI grant 2014SGR647. PV was supported by Grant AZV MZCR: 15-27,580 by the Czech Ministry of Health.

\section{Availability of data and materials}

The datasets generated and/or analysed during the current study are not publicly available due incompatibility with the regulation of the Ethics committee of one of the centers but are available from the corresponding author on reasonable request.

\section{Authors' contributions}

$J B$ performed the genotyping the statistical analyses and drafted the manuscript; MA performed in silico analyses; ST, MC, MDM, FG, RM, RB, SL, DC planned the study; PV, LV, JK, W, AF, FC, AS, VM, NM, FT, AP, collected the samples and worked in the collection of the clinical and epidemiologic data. All authors read and approved the final manuscript.

\section{Ethics approval and consent to participate}

All individuals signed a written consent form and the study was approved by the ethical commissions of the participating centers which were: the Ethics committee of Third medical Faculty, Charles University (22.4.2004), and Ethical committee of Institute of Experimental medicine ASCR, 26.3. 2004, the Kaunas regional ethics committee". Protocol No. BE-10-2, the ethical review board of IRCCS Scientific Institute and Regional General Hospital "Casa Sollievo della Sofferenza", San Giovanni Rotondo, Italy Protocol No. 120/CE and the Bellvitge University Hospital Ethics Committee of Clinical Research, (protocol PR074/11, approved on 24/03/2011).

Consent for publication

Not applicable.

\section{Competing interests}

The authors declare that they have no competing interests.

\section{Publisher's Note}

Springer Nature remains neutral with regard to jurisdictional claims in published maps and institutional affiliations.

\footnotetext{
Author details

${ }^{1}$ Department of Biology, University of Pisa, Via Derna 1, 56100 Pisa, Italy. ${ }^{2}$ Department of Molecular Biology of Cancer, Institute of Experimental Medicine, Academy of Science of Czech Republic, Prague, Czech Republic. ${ }^{3}$ Institute of Biology and Medical Genetics, 1st Medical Faculty, Charles University, Prague, Czech Republic. ${ }^{4}$ Biomedical Centre, Medical School Pilsen, Charles University in Prague, Pilsen, Czech Republic. ${ }^{5}$ Department of Gastroenterology, Lithuanian University of Health Sciences, Kaunas, Lithuania. ${ }^{6}$ Genomic Epidemiology Group, German Cancer Research Center (DKFZ), Heidelberg, Germany. ${ }^{7}$ Division of Molecular Genetic Epidemiology, German Cancer Research Center (DKFZ), Heidelberg, Germany. ${ }^{8}$ Cancer Prevention and Control Program, Catalan Institute of Oncology (ICO), IDIBELL, CIBERESP and Department of Clinical Sciences, Faculty of Medicine, University of
} 
Barcelona, Barcelona, Spain. ${ }^{9}$ Division of Gastroenterology and Research Laboratory, IRCCS Scientific Institute and Regional General Hospital "Casa Sollievo della Sofferenza", San Giovanni Rotondo, Italy.

\section{Received: 26 April 2017 Accepted: 29 August 2017} Published online: 15 September 2017

\section{References}

1. Ervik FLM, Ferlay J, Mery L, Soerjomataram I, Bray F. Cancer Today. Lyon: International Agency for Research on Cancer; 2016. Available from: http:// gco.iarc.fr/today. Accessed 20 Mar 2017.

2. Marley AR, Nan H. Epidemiology of colorectal cancer. Int J Mol Epidemiol Genet. 2016;7(3):105-14.

3. Peters U, Bien S, Zubair N. Genetic architecture of colorectal cancer. Gut. 2015;64(10):1623-36

4. Vymetalkova V, Pardini B, Rosa F, Di Gaetano C, Novotny J, Levy M, Buchle T, Slyskova J, Vodickova L, Naccarati A, et al. Variations in mismatch repair genes and colorectal cancer risk and clinical outcome. Mutagenesis. 2014; 29(4):259-65.

5. Andersen $\mathrm{V}$, Egeberg $\mathrm{R}$, Tjonneland $\mathrm{A}$, Vogel U. ABCC2 transporter gene polymorphisms, diet and risk of colorectal cancer: a Danish prospective cohort study. Scand J Gastroenterol. 2012;47(5):572-4.

6. Andersen $\mathrm{V}$, Vogel U. Interactions between meat intake and genetic variation in relation to colorectal cancer. Genes Nutr. 2015;10(1):448,

7. Campa D, Pardini B, Naccarati A, Vodickova L, Novotny J, Forsti A, Hemminki K, Barale R, Vodicka P, Canzian F. A gene-wide investigation on polymorphisms in the ABCG2/BRCP transporter and susceptibility to colorectal cancer. Mutat Res. 2008:645(1-2):56-60.

8. Campa D, Pardini B, Naccarati A, Vodickova L, Novotny J, Steinke V, Rahner N, Holinski-Feder E, Morak M, Schackert HK, et al. Polymorphisms of genes coding for ghrelin and its receptor in relation to colorectal cancer risk: a two-step gene-wide case-control study. BMC Gastroenterol. 2010;10:112.

9. Campa D, Sainz J, Pardini B, Vodickova L, Naccarati A, Rudolph A, Novotny J, Forsti A, Buch S, von Schonfels W, et al. A comprehensive investigation on common polymorphisms in the MDR1/ABCB1 transporter gene and susceptibility to colorectal cancer. PLoS One. 2012;7(3):e32784.

10. Campa D, Vodicka P, Pardini B, Novotny J, Forsti A, Hemminki K, Barale R, Canzian F. Could polymorphisms in ATP-binding cassette C3/multidrug resistance associated protein 3 (ABCC3/MRP3) modify colorectal cancer risk? Eur J Cancer. 2008;44(6):854-7.

11. Dik VK, Bueno-de-Mesquita HB, Van Oijen MG, Siersema PD, Uiterwaal CS, Van Gils CH, Van Duijnhoven FJ, Cauchi S, Yengo L, Froguel P, et al. Coffee and tea consumption, genotype-based CYP1A2 and NAT2 activity and colorectal cancer risk-results from the EPIC cohort study. Int J Cancer. 2014; 135(2):401-12

12. Ferrari $P$, McKay JD, Jenab M, Brennan P, Canzian F, Vogel U, Tjonneland A, Overvad K, Tolstrup JS, Boutron-Ruault MC, et al. Alcohol dehydrogenase and aldehyde dehydrogenase gene polymorphisms, alcohol intake and the risk of colorectal cancer in the European prospective investigation into cancer and nutrition study. Eur J Clin Nutr. 2012:66(12):1303-8.

13. Kopp TI, Andersen V, Tjonneland A, Vogel U. Polymorphisms in ATP-binding cassette transporter genes and interaction with diet and life style factors in relation to colorectal cancer in a Danish prospective case-cohort study. Scand J Gastroenterol. 2015:50(12):1469-81.

14. Liao LH, Zhang H, Lai MP, Lau KW, Lai AK, Zhang JH, Wang Q, Wei W, Chai $\mathrm{JH}$, Lung ML, et al. The association of CYP2C9 gene polymorphisms with colorectal carcinoma in Han Chinese. Clin Chim Acta. 2007;380(1-2):191-6.

15. Landi S, Bottari F, Gemignani F, Gioia-Patricola L, Guino E, Osorio A, de Oca J, Capella G, Canzian F, Moreno V. Interleukin-4 and interleukin-4 receptor polymorphisms and colorectal cancer risk. Eur J Cancer. 2007;43(4):762-8.

16. Landi S, Gemignani F, Bottari F, Gioia-Patricola L, Guino E, Cambray M, Biondo S, Capella G, Boldrini L, Canzian F, et al. Polymorphisms within inflammatory genes and colorectal cancer. J Nega Results Biomed. 2006;5:15.

17. Vogel LK, Saebo M, Hoyer H, Kopp TI, Vogel U, Godiksen S, Frenzel FB, Hamfjord J, Bowitz-Lothe IM, Johnson E, et al. Intestinal PTGS2 mRNA levels, PTGS2 gene polymorphisms, and colorectal carcinogenesis. PLoS One. 2014; 9(8):e105254.

18. Rudolph A, Sainz J, Hein R, Hoffmeister M, Frank B, Forsti A, Brenner $H_{\text {, }}$ Hemminki K, Chang-Claude J. Modification of menopausal hormone therapy-associated colorectal cancer risk by polymorphisms in sex steroid signaling, metabolism and transport related genes. Endocr Relat Cancer. 2011;18(3):371-84.

19. Sainz J, Rudolph A, Hoffmeister M, Frank B, Brenner H, Chang-Claude J, Hemminki K, Forsti A. Effect of type 2 diabetes predisposing genetic variants on colorectal cancer risk. J Clin Endocrinol Metab. 2012;97(5):E845-51.

20. Landi D, Gemignani F, Landi S. Role of variations within microRNA-binding sites in cancer. Mutagenesis. 2012;27(2):205-10.

21. Landi D, Gemignani F, Pardini B, Naccarati A, Garritano S, Vodicka P, Vodickova L, Canzian F, Novotny J, Barale R, et al. Identification of candidate genes carrying polymorphisms associated with the risk of colorectal cancer by analyzing the colorectal mutome and microRNAome. Cancer. 2012 118(19):4670-80.

22. Campa D, Vodicka P, Pardini B, Naccarati A, Carrai M, Vodickova L, Novotny J, Hemminki K, Forsti A, Barale R, et al. A gene-wide investigation on polymorphisms in the taste receptor 2R14 (TAS2R14) and susceptibility to colorectal cancer. BMC Med Genet. 2010;11:88

23. Carrai M, Steinke V, Vodicka P, Pardini B, Rahner N, Holinski-Feder E, Morak M, Schackert HK, Gorgens H, Stemmler S, et al. Association between TAS2R38 gene polymorphisms and colorectal cancer risk: a case-control study in two independent populations of Caucasian origin. PLoS One. 2011;6(6):e20464.

24. Schembre SM, Cheng I, Wilkens LR, Albright $C L$, Marchand le L. Variations in bitter-taste receptor genes, dietary intake, and colorectal adenoma risk. Nutr Cancer. 2013;65(7):982-90.

25. Hinrichs AL, Wang JC, Bufe B, Kwon JM, Budde J, Allen R, Bertelsen S, Evans W, Dick D, Rice J, et al. Functional variant in a bitter-taste receptor (hTAS2R16) influences risk of alcohol dependence. Am J Hum Genet. 2006; 78(1):103-11.

26. Wang JC, Hinrichs AL, Bertelsen S, Stock H, Budde JP, Dick DM, Bucholz KK, Rice J, Saccone N, Edenberg HJ, et al. Functional variants in TAS2R38 and TAS2R16 influence alcohol consumption in high-risk families of AfricanAmerican origin. Alcohol Clin Exp Res. 2007;31(2):209-15.

27. Mangold JE, Payne TJ, Ma JZ, Chen G, Li MD. Bitter taste receptor gene polymorphisms are an important factor in the development of nicotine dependence in African Americans. J Med Genet. 2008:45(9):578-82.

28. Behrens M, Meyerhof W. Oral and extraoral bitter taste receptors. Results Probl Cell Differ. 2010;52:87-99.

29. Clark AA, Liggett SB, Munger SD. Extraoral bitter taste receptors as mediators of off-target drug effects. FASEB J. 2012;26(12):4827-31.

30. Rozengurt E, Sternini C. Taste receptor signaling in the mammalian gut. Curr Opin Pharmacol. 2007:7(6):557-62.

31. Sternini C. Taste receptors in the gastrointestinal tract. IV. Functiona implications of bitter taste receptors in gastrointestinal chemosensing. Am J Physiol Gastrointest Liver Physiol. 2007;292(2):G457-61.

32. Bufe B, Hofmann T, Krautwurst D, Raguse JD, Meyerhof W. The human TAS2R16 receptor mediates bitter taste in response to betaglucopyranosides. Nat Genet. 2002;32(3):397-401.

33. Vane JR. The fight against rheumatism: from willow bark to COX-1 sparing drugs. J Physiol Pharmacol. 2000;51(4 Pt 1):573-86.

34. Singh Ranger $\mathrm{G}$. The role of aspirin in colorectal cancer chemoprevention. Crit Rev Oncol Hematol. 2016;104:87-90.

35. Hua X, Phipps Al, Burnett-Hartman AN, Adams SV, Hardikar S, Cohen SA, Kocarnik JM, Ahnen DJ, Lindor NM, Baron JA, et al. Timing of aspirin and other nonsteroidal anti-inflammatory drug use among patients with colorectal cancer in relation to tumor markers and survival. J Clin Oncol. 2017. JCO.2017.2072.3569.

36. Campbell MC, Ranciaro A, Zinshteyn D, Rawlings-Goss R, Hirbo J, Thompson S, Woldemeskel D, Froment A, Rucker JB, Omar SA, et al. Origin and differential selection of allelic variation at TAS2R16 associated with salicin bitter taste sensitivity in Africa. Mol Biol Evol. 2014;31(2):288-302.

37. Kupcinskas J, Bruzaite I, Juzenas S, Gyvyte U, Jonaitis L, Kiudelis G, Skieceviciene J, Leja M, Pauzas H, Tamelis A, et al. Lack of association between miR-27a, miR-146a, miR-196a-2, miR-492 and miR-608 gene polymorphisms and colorectal cancer. Sci Rep. 2014;4:5993.

38. Kupcinskas J, Gyvyte U, Bruzaite I, Leja M, Kupcinskaite-Noreikiene R, Pauzas $H$, Tamelis A, Jonaitis L, Skieceviciene J, Kiudelis G. Common genetic variants of PSCA, MUC1 and PLCE1 genes are not associated with colorectal cancer. Asian Pac J Cancer Prev. 2015;16(14):6027-32.

39. Moreno V, Gemignani F, Landi S, Gioia-Patricola L, Chabrier A, Blanco I, Gonzalez S, Guino E, Capella G, Canzian F. Polymorphisms in genes of nucleotide and base excision repair: risk and prognosis of colorectal cancer. Clin Cancer Res. 2006;12(7 Pt 1):2101-8. 
40. Barrett JC, Fry B, Maller J, Daly MJ. Haploview: analysis and visualization of LD and haplotype maps. Bioinformatics. 2005;21(2):263-5.

41. Boyle AP, Hong EL, Hariharan M, Cheng Y, Schaub MA, Kasowski M, Karczewski $\mathrm{KJ}$, Park J, Hitz BC, Weng S, et al. Annotation of functional variation in personal genomes using RegulomeDB. Genome Res. 2012;22(9):1790-7.

42. Ward LD, Kellis M. HaploReg: a resource for exploring chromatin states, conservation, and regulatory motif alterations within sets of genetically linked variants. Nucleic Acids Res. 2012;40(Database issue):D930-4.

43. Consortium G. The genotype-tissue expression (GTEx) project. Nat Genet. 2013;45(6):580-5.

44. Choi JH, Lee J, Choi IJ, Kim YW, Ryu KW, Kim J. Variations in TAS1R taste receptor gene family modify food intake and gastric cancer risk in a Korean population. Mol Nutr Food Res. 2016;60(11):2433-45.

45. Choi JH, Lee J, Choi IJ, Kim YW, Ryu KW, Kim J. Genetic variation in the TAS2R38 bitter taste receptor and gastric cancer risk in Koreans. Sci Rep. 2016;6:26904.

Submit your next manuscript to BioMed Central and we will help you at every step:

- We accept pre-submission inquiries

- Our selector tool helps you to find the most relevant journal

- We provide round the clock customer support

- Convenient online submission

- Thorough peer review

- Inclusion in PubMed and all major indexing services

- Maximum visibility for your research

Submit your manuscript at www.biomedcentral.com/submit
Biomed Central 